\title{
Technological Aspects of the Use of Lentil Proteins in the Production of Raw Smoked Sausages
}

\author{
Ju. A. Ovchinnikova ${ }^{1}$, A.A. Nesterenko ${ }^{1}$, N.P. Oboturova ${ }^{2}$, O.A. Baklanova ${ }^{2}$, L.I. \\ Barybina $^{2}$, I.S. Baklanov ${ }^{2}$, A.V. Klopova ${ }^{3}$, A.A. Nagdalian ${ }^{2 *}$ \\ ${ }^{1}$ Kuban State Agrarian University named after I. T. Trubilin, 13 Kalinina Street, Krasnodar, 350044, Russia. \\ ${ }^{2}$ North Caucasus Federal University, 1 Pushkina Street, Stavropol, 355009, Russia. \\ ${ }^{3}$ Don State Agrarian University, 24 Krivoshlykova Street, Persianovskiy Village, Oktyabrsky District, Rostov Region, \\ Russia, 346493.
}

\begin{abstract}
Plant proteins are widely used in the production technology of sausage products. They are used to improve the functional and technological properties of ground sausage and increase the yield of finished products. The article presents the technical aspects of the use of lentil proteins in the production of raw smoked sausages. The changes in the $\mathrm{pH}$ value of minced meat and sausage and the speed of maturation and drying are evaluated and justified. The results of histological analysis, organoleptic examination, and research of physical and chemical properties of the finished products are presented in the article.

Key Words: Plant proteins, Lentils, Raw smoked sausages, Minced meat, Raw meat.
\end{abstract}

eIJPPR 2020; 10(6):246-251

HOW TO CITE THIS ARTICLE: Ju. A. Ovchinnikova, A.A. Nesterenko, N.P. Oboturova, O.A. Baklanova, L.I. Barybina, I.S. Baklanov and et al. (2020). "Technological Aspects of the Use of Lentil Proteins in the Production of Raw Smoked Sausages", International Journal of Pharmaceutical and Phytopharmacological Research, 10(6), pp.246-251.

\section{INTRODUCTION}

The plant seeds are well known for their nutritional value. Due to the shortage of meat raw materials, meat processing enterprises have switched to technologies with partial replacement of meat raw materials with plant proteins $[1,2]$. These technologies allow us to provide the finished product with a balanced protein. Modern studies indicate the possibility of using various plant proteins in the production technology of meat products [3-7]. Slozhenkina M.I. (2015), Barybina L.I. (2018), Nesterenko A.A. $(2017 ; 2018)$ studied the issues of the use of plant proteins in the production technology of raw smoked sausage products in the works of [8-10].

Usage of a starter culture is very important in the production of raw smoked sausages to improve and accelerate maturation. The issues of biomodification of minced meat with the addition of plant proteins are described in [11-14]

Scientific studies of the use of lentil proteins in the preparation of model minced meat for raw smoked sausages are presented in the works of $[10,15]$. The authors have been created a model of minced meat and studied the effect of lentil proteins introduction on the functional, technological, physical, and chemical properties. It was found that lentil proteins reduce the Water Holding Capacity (WHC) and Moisture-retaining Power (MRP). Reduction of the WHC and MRP is usually a negative effect for cooked sausage, but in the technology of raw smoked sausage production, it is a positive effect. That effect activates the development of the starting microflora compared to the control as a result of the appearance of an additional nutrient medium in the form of plant polysaccharides and an increase of water activity. Thus, a rapid and even decrease in the $\mathrm{pH}$ of minced meat can contribute to a decrease in the amount of "wild" microbes as a result of the intensive accumulation of lactic acid. Reducing the $\mathrm{pH}$ to the isoelectric point of the protein will ensure fast drying of sausages.

The article is a scientific study conducted within the framework of the master's thesis of Ovchinnikova Ju. A. on the topic: "Improvement of the Recipe and Technology of Raw Smoked Sausages with the Use of Plant Components" which was carried out in 2020 with the scientific advice of the authors of the work.

The Purpose of the Work: To study the possibility of using lentil proteins in the production technology of raw

Corresponding author: Nagdalian Andrey Ashotovich

Address: Pushkina Street, Stavropol, 355009, Russia

E-mail: $\bowtie$ geniando @ yandex.ru

Relevant conflicts of interest/financial disclosures: The authors declare that the research was conducted in the absence of any commercial or financial relationships that could be construed as a potential conflict of interest.

Received: 18 October 2020; Revised: 20 Decmber 2020; Accepted: 23 December 2020 
smoked sausages

\section{MATERIALS AND METHODS}

To prepare a trial batch of sausage products, the recipe composition "Braunschweig" according to GOST R 55456-2013 was taken [16]. The recipe compositions are presented in Table 1.

Table 1. Recipes of the Experimental Sausage based on the "Braunschweig" Sausage

\begin{tabular}{|c|c|c|}
\hline Components & $\begin{array}{c}\text { "Braunschweig" } \\
\text { Sausage, } \%\end{array}$ & $\begin{array}{c}\text { Experimental } \\
\text { Sausage, } \%\end{array}$ \\
\hline $\begin{array}{c}\text { Trimmed of the highest } \\
\text { grade }\end{array}$ & 45 & 25 \\
\hline Trimmed lean pork & 25 & 25 \\
\hline Fatback & 30 & 30 \\
\hline Lentil protein & - & 20 \\
\hline Salt (NaCl) & 2 & 2 \\
\hline Ground black pepper & 0,1 & 0,1 \\
\hline Nitrite salt & 1.5 & 1.5 \\
\hline Sugar & 0,2 & 0,2 \\
\hline Nutmeg & 0,03 & 0,03 \\
\hline Starter cultures & 0,1 & 0,1 \\
\hline
\end{tabular}

Minced meat was prepared on a cutter by the method of sequential loading from low-fat raw materials to fat. As a starter culture was taken "Bassstrait" (Mongolia LLC, Russia). The culture includes microorganisms of the species P. pentosaceus, Staphylococcus xylosus, and Staphylococcus carnosus.
The $\mathrm{pH}$ was determined using a $\mathrm{pH}-340$ potentiometer according to GOST R 51478-99 [17].

Mass changes were determined by weighing on a scale and in a ratio of $\%$ to the weight of the feedstock. The determination of the mass fraction of moisture in the raw material and the product was carried out by the method of drying to a constant mass following GOST 9793-74 [18]. Drying was carried out at a temperature of $105{ }^{\circ} \mathrm{C}$. Histological studies were performed according to the method proposed by Gurova S. V., Barabanov I. I., Minchina L. S., Khvylya S. I. [19, 20]. The study of the microstructure of samples on histological preparations and their photographing with digital photographic equipment was carried out on an AXIOIMIGER.A1 light microscope (Carl Zeiss, Germany) with the connected AXIOVISION image analysis system using the appropriate morphological computer program at lens magnifications from $\times 2$ to $\times 63$. The analysis of the consistency density of the finished product was carried out by a method based on the analysis of the force required for the destruction of a sample of sausage products by cutting in a constant volume chamber [21].

\section{RESULTS}

The production of raw sausages experimental and control of the party sausage products were made according to the scheme presented in Figure 1. Testing was performed in the conditions of an educational and scientific production complex "Agrobiotehpererabotka" in the Kuban State Agrarian University.

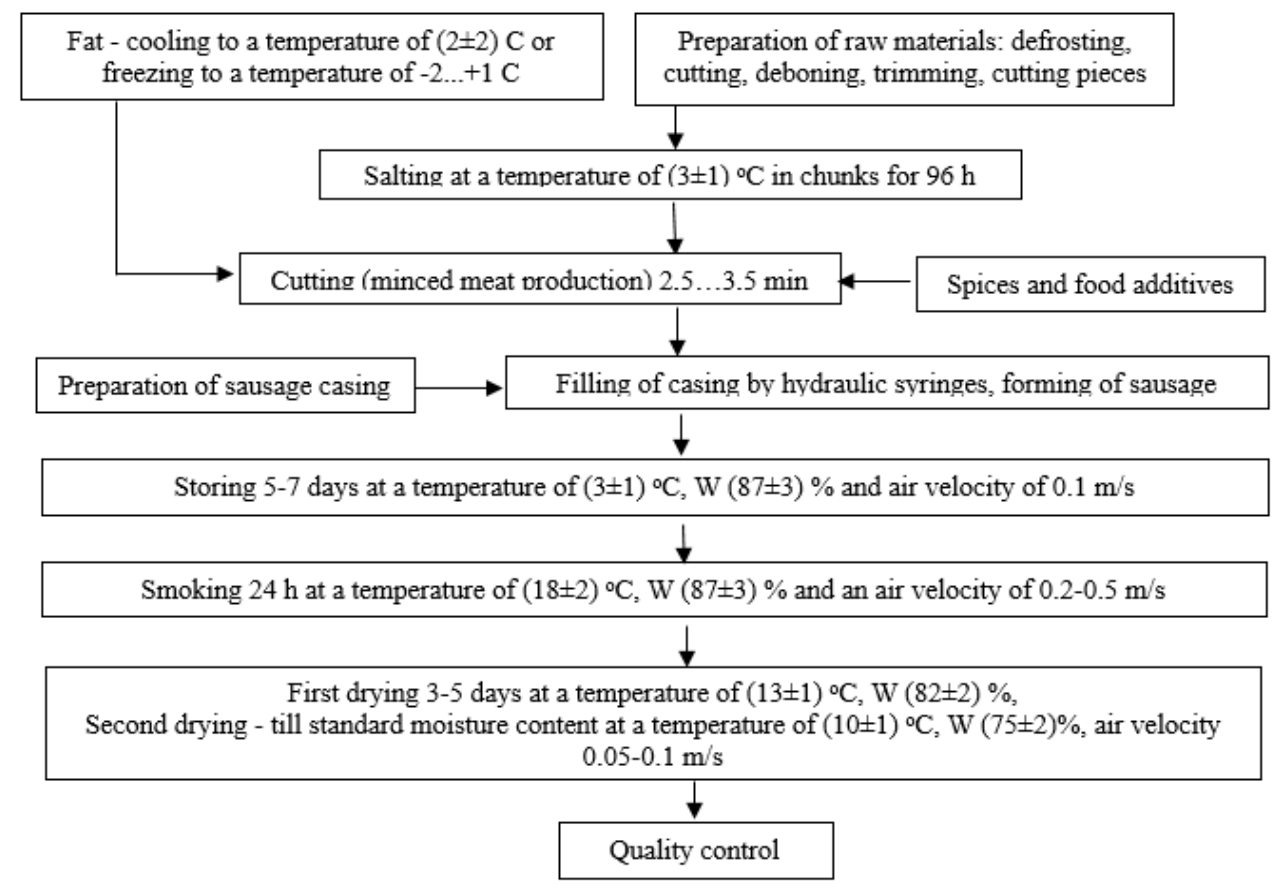

Figure 1. Scheme of Production of Raw Smoked Sausage 
During the production of sausage products, changes in the $\mathrm{pH}$ value were monitored during all technological operations.

The $\mathrm{pH}$ change during the storing, smoking, and drying of raw sausages is shown in Figure 2.

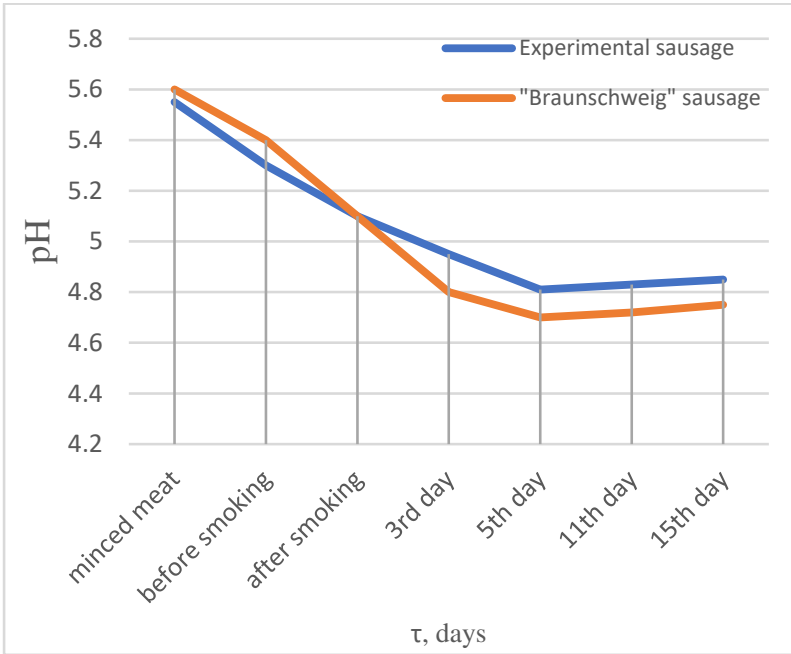

Figure 2. Dynamics of Changes in the pH of Samples of Raw Smoked Sausages

Figure 2 shows that the decrease of $\mathrm{pH}$ in the experimental batch at the first stages of production is faster, which is due to the intensive development of the starting microflora and the accumulation of lactic acid. The dependence of moisture content on the duration of drying is shown in Figure 3.

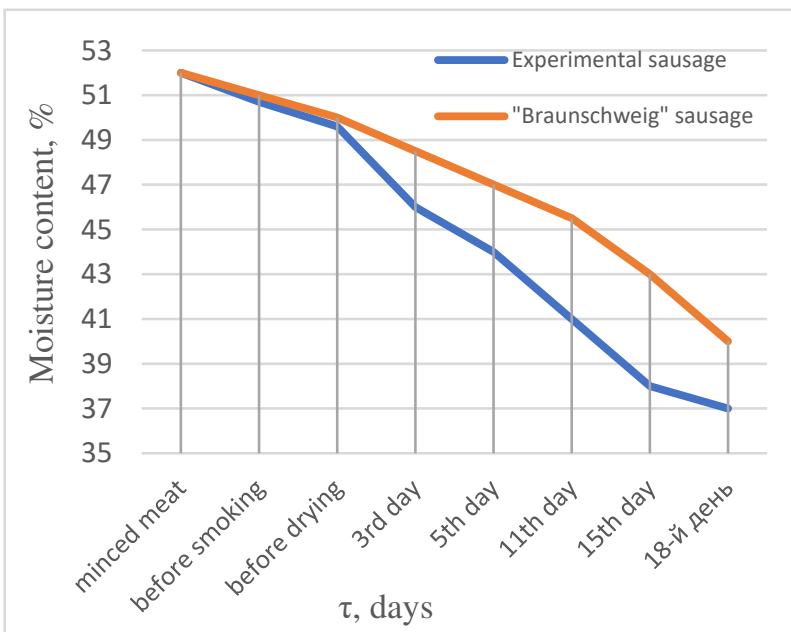

Figure 3. Dependence of Moisture Content on the Drying Duration

In the experimental sample of the model minced meat, a faster drying rate is observed at 3-5 days, compared to the control. Reducing the drying time helps to reduce production costs.

The histological analysis of sausage samples showed the development of maturation. The homogeneity of the cell contents is observed. The transverse striation and partially the cell nuclei were disappeared. Analysis of muscle fiber showed the destruction of fibrillar proteins and sarcolemma (Figure 4).

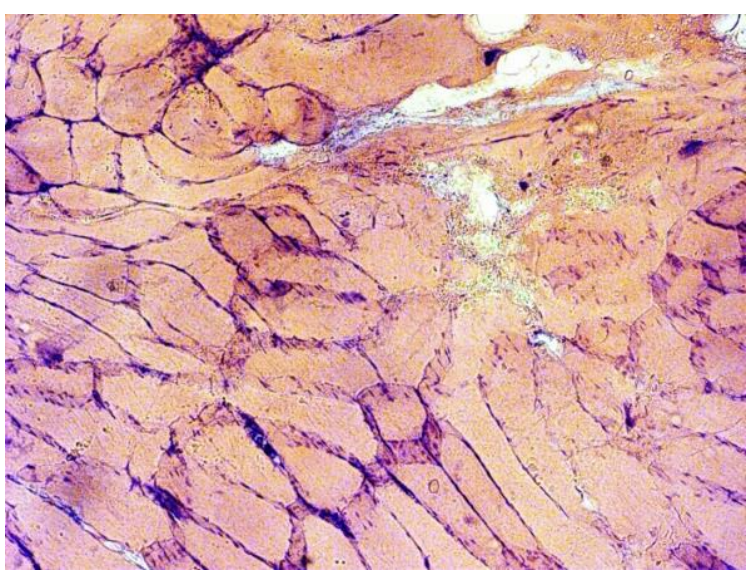

Figure 4. Histological Section of Experimental Sample (hematoxylin-eosin, $\times 200$ ).

Between the fragments of connective tissue and muscle fibers, there is an accumulation of fine-grained protein mass. According to the structure of the mass, it can be concluded that these are lentil proteins (Figure 5). Between the structural elements of sausage minced meat, there are a large number of pores that are not characteristic of raw smoked sausages.

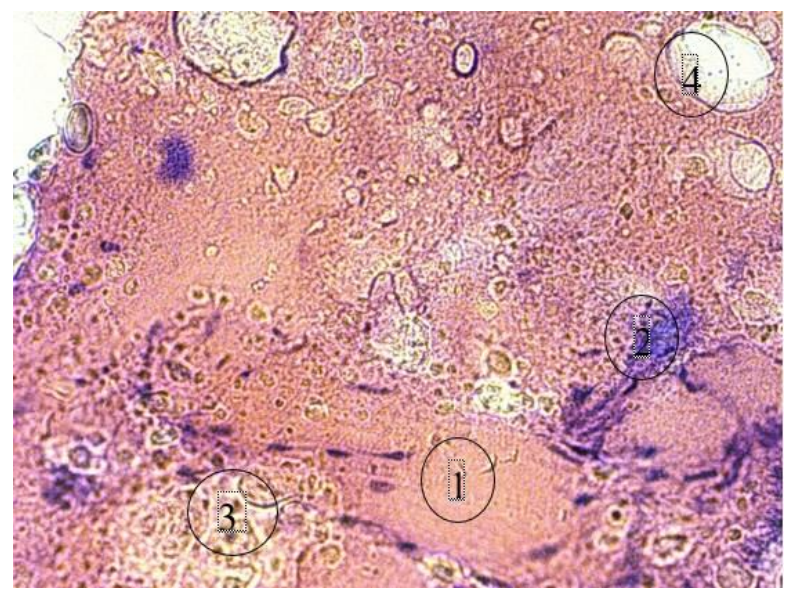

Figure 5. Analysis of the Muscle Fiber of the

Experimental Sample (hematoxylin-eosin, $\times 200)$.

1- Fragments of Muscle Fibers; 2-

Microorganisms; 3- Micropores;

4- Fat Inclusions

Histological analysis of the experimental sample showed the presence of microflora both in separate parts and scattered around the perimeter of the minced meat. To a greater extent, the microflora is located in a fine-grained protein mass.

Organoleptic evaluation of finished products was performed at the Department of Technology of Storage 
and Processing of Livestock Products of the Kuban State Agrarian University following GOST 9959-2015.

It is noted that the appearance of the sausage corresponds to GOST R 55456-2013 [16]: sausages with a clean, dry surface, without stains, slips, damages to the casing, and bursts (Figure 6).
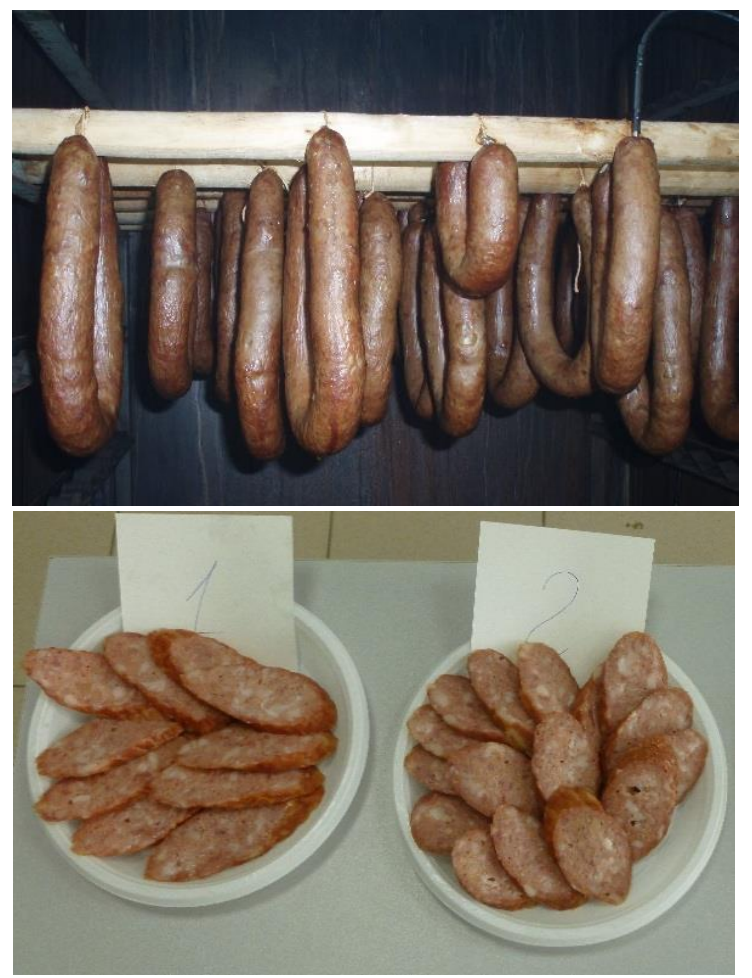

Figure 6- Finished Sausage Products

The organoleptic evaluation was carried out on a 5-point scale. The organoleptic profile of the experimental and control sample was compiled and shown in Figure 7.

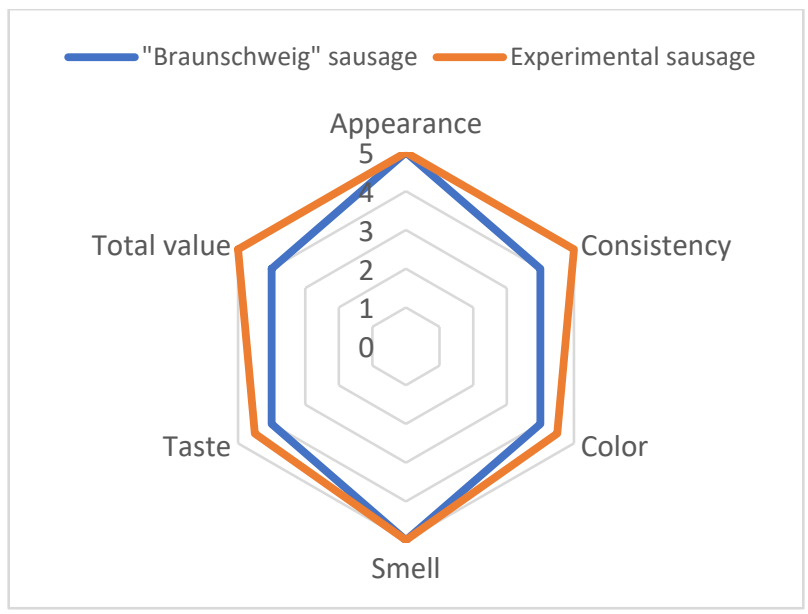

Figure 7. Organoleptic Profile

The organoleptic characteristics of the finished product remained unchanged throughout the entire shelf life and corresponded to the regulatory documentation.
Tasters noted a denser consistency of the experimental sausage products. The analysis of the structural and mechanical characteristics of the finished product showed that the cut-off voltage of the experimental batch of sausage products was $567.60 \mathrm{kPa}$, the sausages from the control batch showed a result of $487.9 \mathrm{kPa}$. The results obtained indicate a denser consistency of the experimental batch of sausage products.

The physical and chemical parameters of the experimental sample are presented in Table 2 .

Table 2- Physical and Chemical Parameters of the Experimental Sample

\begin{tabular}{|c|c|c|}
\hline Index & $\begin{array}{c}\text { Acceptable } \\
\text { Value }\end{array}$ & $\begin{array}{c}\text { Experimental } \\
\text { Sample }\end{array}$ \\
\hline Moisture content, \% & 42,0 & 37,9 \\
\hline Fat content, \% & 57 & 31,1 \\
\hline Protein content, \% & 8,0 & 22,1 \\
\hline pH, a.u. & 4,8 & 5,2 \\
\hline $\mathrm{NaCl}$ content, \% & 6,0 & 4,0 \\
\hline $\mathrm{NaNO}_{2}$ content, \% & 0,005 & 0,0017 \\
\hline
\end{tabular}

\section{DISCUSSION:}

$\mathrm{pH}$ is an important indicator in the production of raw smoked sausages. A rapid decrease in the $\mathrm{pH}$ value contributes to the formation of a dense consistency of minced meat. The activity of intracellular enzymes increases with low $\mathrm{pH}$. The optimal $\mathrm{pH}$ for intracellular enzymes varies in the range of 3.8-5.0 [22]. In an experimental batch of sausages is a more active reduction of $\mathrm{pH}$, compared with the control sample, but the decrease in $\mathrm{pH}$ is terminating at point 4.9. Active development of starter cultures due to the introduction of lentils protein and additional nutrient medium. The obtained data are confirmed by the conducted studies [10].

According to the technology, smoking is carried out when the $\mathrm{pH}$ of the minced meat reaches from 5.1 to 5.4, and significant indicators are also taken into account: the density and color of the minced meat. The $\mathrm{pH}$ of the experimental batch decreases faster than in the control, therefore, the setting for smoking can be carried out in a shorter period. At the same time, the reduction in the precipitation period of sausage will significantly affect the economic efficiency of production.

Another important technological indicator in the production of raw smoked sausage products is the drying speed. It depends on such indicators as $\mathrm{pH}$, temperature, humidity, and air velocity [23]. The introduction of plant proteins into the recipe composition contributes to an accelerated drying process. Plant proteins with a lower $\mathrm{pH}$ "give" water more efficiently than proteins of animal origin. As a result, the drying of sausage products of the 
experimental batch is carried out with greater intensity compared to the control. At the same time, plant proteins form microcapillaries in minced meat structure. Formed microcapillaries accelerate the diffusion of moisture from the center of the sausage to the periphery.

The introduction of plant components to a small extent had an impact on the taste and color of the finished product. However, the organoleptic commission noted that the prototype has a more pronounced taste and aroma properties and a dense consistency. Due to the more intensive drying (experimental samples reached normal $40 \%$ on the $14^{\text {th }}$ day, control - on $18^{\text {th }}$ day) experimental sausages had a denser consistency, as evidenced by the results of structural and mechanical studies.

The physical and chemical parameters of the finished products meet the requirements of GOST R 55456-2013 [16].

\section{CONCLUSION}

In the course of the research, changes in physical and chemical parameters from minced meat to finished products were studied. It was found that the addition of lentil proteins to the recipe composition accelerates the maturation process (a reduction of 48 hours) and drying of sausage loaves (a reduction of 5 days) compared to the control.

The results of the study were tested in the conditions of the educational and scientific production complex "Agrobiotehpererabotka" of the Kuban State Agrarian University.

Partial replacement of meat raw materials with lentil proteins has a positive effect on the organoleptic characteristics of the finished product. The physical and chemical parameters of the developed products meet the requirements of GOST R 55456-2013.

\section{REFERENCES}

[1] Choudhary NK, Mallya R. Phytochemical investigation and antibacterial activity of a medicinal plant. Int. J. Pharm. Phytopharm. Res. 2019;9(4):538.

[2] Benzineb E, Kambouche N, Hamiani A, Bellahouel S, Zitouni H, Toumi H. Phenolics Compounds and Biological Activity of Leaves of Anabasis Articulata, an Algerian Medicinal Plant. Int. J. Pharm. Res. Allied Sci. 2019;8(4):1-5.

[3] Zinina O, Rebezov M, Khayrullin M, Neverova O, Bychkova T. Functional and technological indicators of fermented minced meat. IOP Conf. Ser.: Earth Environ. Sci. 2020;548, 082010. https://doi:10.1088/1755-1315/548/8/082010
[4] Rebezov MB, Zhumanova GT. Application of mathematical modeling and the principles of qualimetric forecasting in the production of semifinished horse meat products with the use of a protein fortifier IOP Conf. Series: Earth and Environmental Science, $\quad 2020 ; 613(1)$ : 012120. https://doi:10.1088/1755-1315/613/1/012120

[5] Kambarova A, Nurgazezova A, Nurymkhan G, Atambayeva Z, Smolnıkova F, Rebezov M, et al. Improvement of quality characteristics of turkey pâté through optimization of a protein rich ingredient: physicochemical analysis and sensory evaluation. Food Sci. $\quad 2020$. https://doi.org/10.1590/fst.00720.

[6] Okuskhanova E, Rebezov M, Yessimbekov Zh, Suychinov A, Semenova N, Rebezov Ya, et al. Study of water binding capacity, $\mathrm{pH}$, chemical composition and microstructure of livestock meat and poultry. Annu. Res. Rev. Biol. 2017;14(3):1-7. https://doi:10.9734/ARRB/2017/34413

[7] Okuskhanova E, Smolnikova F, Kassymov S, Zinina O, Mustafayeva A, Rebezov M, et al. Development of minced meat ball composition for population from the unfavorable ecological regions. Annu. Res. Rev. Biol.

2017;13(3):1-9. https://doi:10.9734/ARRB/2017/33337

[8] Slozhenkina MI, Kuznetsova EA, Starodubova Yu V, Chepelenko MN. Expediency of using of vegetable proteins texturate in the production of ham products. Izvestiya Nizhnevolzhskogo agrouniversitetskogo kompleksa: Nauka i vysshego professionalnoe obrazovanie, 2015;1(37):161-4.

[9] Barybina LI, Voblikova TV, Beloysova EV, NAgdalian AA, Oboturova NP, Sergeev AA. Usage Of Vegetable Stuff In Dry Sausage Production. Res. J. Pharm. Biol. Chem. Sci. 2018;9(4):1536-40.

[10] Nesterenko AA, Kenijz NV. Scientific and practical bases of application of vegetable proteins of wheat grain in food technology. Krasnodar, Kuban State Agrarian University, 2018:172.

[11] Nesterenko AA, Koshchaev AG, Kenijz NV, Shhalahov DS, Vilts KR. Effect of low frequency electromagnetic treatment on raw meat. Res. J. Pharm. Biol. Chem. Sci. 2017;8(1):1071-9.

[12] Omarov RS, Shlykov SN, Nesterenko AA. Obtaining a biologically active food additive based on formed elements blood of farm animals. Res. J. Pharm. Biol. Chem. Sci. 2018;9(6):1832-8.

[13] Nagdalian AA, Oboturova NP, Povetkin SN, Ziruk IV, Egunova A, Simonov AN, et al. Adaptogens instead restricted drugs research for an alternative Items to doping in sport. Res. J. Pharm. Biol. Chem. Sci. 2018; 9(2):1111-6. 
[14] Barabanov PV, Gerasimov AV, Blinov AV, Kravtsov AA, Kravtsov VA. Influence of nanosilver on the efficiency of Pisum sativum crops germination, Ecotoxicol. Environ. Saf. 2018;147:715-9

[15] Nesterenko AA, Koshchaev AG, Kenijz NV, Shhalahov DS, Vilts KR. Development of device for electromagnetic treatment of raw meat and starter cultures. Res. J. Pharm. Biol. Chem. Sci. 2017;8(1):1080-5.

[16]GOST R 55456-2013 Raw smoked sausages. Technical conditions. Standartinform, Moscow, 17 p.

[17] GOST R 51478-99 Meat and meat products. Control method for determining the concentration of hydrogen ions $(\mathrm{pH})$ Standartinform, Moscow, $4 \mathrm{p}$.

[18]GOST 9793-74 Meat products. Methods for determining moisture. Standartinform, Moscow, $4 \mathrm{p}$.

[19] Piskov S, Timchenko L, Grimm WD, Rzhepakovsky I, Avanesyan S, Sizonenko M, et al. Effects of various drying methods on some physico-chemical properties and the antioxidant profile and ACE inhibition activity of oyster mushrooms (Pleurotus ostreatus). Foods, 2020;9(2): 9020160

[20] Nagdalian AA, Selimov MA, Topchii MV, Oboturova NP, Gatina YS, Demchenkov EL. Ways to Reduce the Oxidative Activity of Raw Meat after a Treatment By Pulsed Discharge Technology. Res. J. Pharm. Biol. Chem. Sci. 2016;7(3):1927-32.

[21] Sadovoy VV, Selimov MA, Schedrina TV. Usage of Biological Active Supplements in Technology of Prophilactic Meat Products. Res. J. Pharm. Biol. Chem. Sci. 2016;7(5):1861-5.

[22] Solovieva AA, Zinina OV. Effect of Biotechnological Processing on the Microstructure of Smoked Poultry Sausages. Bulletin of the South Ural State University. Ser. Food and Biotechnol. 2016;4(4):45-53. http://DOI:10.14529/food160405

[23] Khramtsov AG, Blinov AV, Blinova AA, Serov AV. Influence of the whey type on composition and properties of its mineralizates. Foods and Raw Materials. 2017;5(1):30-40. 